\title{
FUTURE OF WEST AFRICAN UNIVERSITIES
}

$\mathrm{U}$ NIVERSITIES in those parts of tropical Africa which began under British influence have entered a new phase in their development. Political changes have created the demand for increased facilities for higher education and have forced on the universities the need to re-define their purpose in relation to the societies within which they function. Three major commissions have recently considered these problems in East Africa, in Ghana and in Nigeria (Nature, 184, 243, 1959; 189, 95, 1961; and $192,14,1961)$. The Commission on Higher Education in Nigeria, of which Sir Eric Ashby was the chairman, made a number of detailed proposals concerning expansion and adaptation of university education in that country. In a recent paper*, Patterns of Universities in Non-European Societies, Sir Eric Ashby's thesis is that West African universities must take on themselves a distinct West African identity, developed by a gradual process of growth from their British foundations. At the same time their academic standards must be maintained at the high level they are to-day.

By examining the impact of higher education on India and on West Africa, Sir Eric is able to suggest what changes should be encouraged and what dangers must be avoided in the evolution of West African universities.

In both these regions, universities were not at first sponsored by the indigenous people, but by the Colonial power to impose a new Western culture. The Indian universities were modelled on the University of London as it was in 1850 . They were simply to be examining bodies, drawing their candidates from colleges already established. With a few notable exceptions they have remained little more than examining bodies, without the warmth and fellowship of academic society. Moreover, because of the exclusion from examinations of any subject connected with religion, the universities were cut off from the mainstream of Indian ethical and religious life. Here lie the main causes behind the failure of Indian univer. sities to adapt themselves and become the centre and focus of India's intellectual life.

The West African universities have been more fortunate. The University Colleges at Ibadan and Accra were established as a result of the findings of the

* Patterns of Universities in Non-European Societies. By Sir Eric Ashby. Pp. 27. (London: School of Oriental and African Studies, University of London, 1961.)
Asquith Commission on Higher Education in the Colonies, in 1945. They are universities in the fullest sense-vigorous, cohesive societies of teachers and scholars. To establish high academic standards the curricula and examinations have been tied to the University of London. Though no subjects have been explicitly excluded, little encouragement has been given so far to undergraduate studies in African history, sociology and art. Although, superficially, these subjects have received greater attention in the universities of French West Africa, Sir Eric considers that their expression in the idea of négritude is littlo more than an outburst of cultural racialism, a byproduct of the French educational policy of turning Africans into Frenchmen. British educational policy in West Africa has been less precise and doctrinaire than the French. Within the more liberal framework there is every hope that the encouragement of African studies will help to integrate the universities into African society.

The Asquith Commission did not foresee that the independence of the British West African territories would bring the desire for massive development of the economy and social services; that these, as well as the purely administrative services, would need large numbers of graduates. Less specialization, a greater breadth of knowledge and a modification of the content of courses in agriculture, engineering and medicine to meet the different needs of the countries; these are all desirable. There may also be a case for some modification of the pattern of university government. Research is expensive, and to reduce the burden of cost, research carried out in the universities and in Government institutions should be unified. However, this must not entail a loss of freedom for the university.

The West African universities have reached a stage in their development when change must be made if they are not to become unassimilated and separated from the people. However, adaptation of social institutions is difficult, and to force the pace would be dangerous. Great care must be taken to ensure that the present concern with local culture does not distort the fundamental values of learning which make a university. This is why the adaptation of the universities, which are essentially European institutions, to non-European societies needs intensive and thought ful analysis.

C. T. Mortimer

\section{GEOCHRONOLOGY AND LAND SURFACES IN RELATION TO SOILS IN AUSTRALASIA}

$\mathrm{D}$ URING the Second Australian Conference on Soil Science held in Melbourne in August 1957 it was stressed that the collection of systematic information about the various geomorphic features of the continent would contribute greatly to the understanding of the origin and development of Australian soils and thereby facilitate their mapping and help to explain their fertility characteristics. Arising from this a resolution was passed pointing to the pressing need for a great increase in knowledge of post-Cretaceous chronology in Australia. The resolution was referred by the Australian Academy of Science to the Australian Royal Societies with the result that a symposium on geochronology and land surfaces in relation to soils in Australasia was convened by the Academy at the Laboratories of the Division of Soils, Commonwealth Scientific and Industrial Research Organization, in Adelaide during December 5-8. The meeting, which was opened by Prof. J. A. Prescott, chairman of the organizing committee, was attended by forty-four university, museum, industrial and Government scientists inter- 